\title{
Teaching Nature of Scientific Knowledge to Kindergarten Through University Students
}

\section{Norman G. Lederman ${ }^{1} \cdot$ Fouad Abd-El-Khalick ${ }^{2} \cdot$ Mike U. Smith $^{3}$}

Published online: 30 May 2019

(C) Springer Nature B.V. 2019

\section{Introduction}

The rotunda in the National Academy of Science contains the following inscription: "To science, pilot of industry, conqueror of disease, multiplier of the harvest, explorer of the universe, revealer of nature's laws, eternal guide to truth." The quote is not attributed to any individual. It is not clear if the quote is older than 1936, when the rotunda was built. Nobel Prize-winning physicist Richard Feynman defined science in the 1970s as "the belief in the ignorance of experts" (Feynman and Cashman 2013). More recently, in a personal conversation with the first author, prominent paleobiologist Arthur Boucot characterized science as "an internally consistent set of lies designed to explain away the universe." These different statements are quite varied and, as provocative as Boucot's and Feynman's definitions may be, they are also consonant with how science is characterized in recent US reform documents, such as the Next Generation Science Standards [NGSS] (NGSS Lead States 2013) and the National Science Education Standards (National Research Council 1996).

The question still remains though: "What is science?" What conceptualization would be most appropriate for learners in kindergarten through university $(\mathrm{K}-\mathrm{U})$ education? Commonly, the answer to this question has three parts. First, science is a body of knowledge. This component refers to the traditional subjects, such as biology, chemistry, and physics, and associated bodies of concepts, laws, and theories. The second part refers to how scientific knowledge is developed, that is, scientific inquiry (or what is referred to as "practices" in the NGSS). The third component is nature of scientific knowledge (NOSK), which deals with

Norman G. Lederman

ledermann@iit.edu

Fouad Abd-El-Khalick

fouad@unc.edu

Mike U. Smith

smith_mu@mercer.edu

1 Illinois Institute of Technology, Chicago, IL 60616, USA

2 University of North Carolina at Chapel Hill, Chapel Hill, NC 27599, USA

3 Mercer University School of Medicine, Macon, GA 31207, USA 
more general, philosophical characteristics of scientific content and practices that are more likely to apply (though to differing degrees) across the sciences. Again, this three-part conceptualization of science is easily understood by K-U students and easily mapped onto the curriculum in science classes at all levels. The central purpose here is not to argue about the various nuances in the scientific endeavor but rather to discuss the appropriateness of what we ask our K-U students to learn. Here, we should note that by "K-U" learners we are focused on students in K-12 grades (i.e., school students) and those enrolled in introductory and intermediate level university science courses. These learners will become tomorrow's citizens who will need command of functional scientific literacy, and therefore a robust understanding of the aforementioned features of science, to negotiate an increasingly scientifically and technologically laden world.

\section{Nature of Science or Nature of Sciences?}

In a 2016 paper, Schizas, Psillos, and Stamou argued that science educators should teach, not a generalized nature of science (NOS, or NOSK), but the "nature of the sciences" (NOSs). They argued that we should focus not on the similarities among the sciences - an approach often described as a domain-general or consensus approach to teaching the NOS - but to focus, instead, on the "differences and unique features" of the various sciences (p. 4). Schizas et al. compared physics and biology to make their case and they claimed the domain-general NOS approach may result in "epistemological confusion and various misunderstandings" (p. 726). We respectfully disagree. As educators, we must strike a balance between what most K-U students can understand and ensure that the content is at the depth that is appropriate to prepare them to participate knowledgeably in readings about discussing and understanding science topics as citizens, while not forgetting that NOSK must seamlessly fit with the science curriculum as well. It can, in fact, be argued that teaching about the differences among the various ways that knowledge is attained in the various sciences would be more confusing to students than effectively teaching them about some of the similarities or "general characteristics" of NOSK that apply across the sciences (Abd-El-Khalick 2012a). Indeed, in order for students to be able to appreciate the differences between the various science disciplines, they need to understand what makes them fall in the realm of science in the first place. With regard to quibbling about the dangers of having a domain-general conception of NOSK, Schwartz and Lederman (2008) found that practicing research scientists, spanning the main scientific disciplines, shared largely overlapping understandings of NOSK more than distinctions among the NOSs. When it comes to the actual teaching about NOSK in K-12 classrooms and introductory and intermediate level university courses, one must also pay close attention to the considerable body of empirical research, which speaks to what students can reasonably learn and how NOSK can be effectively taught (Abd-El-Khalick and Lederman 2000; Lederman 2007; Lederman and Lederman 2014).

Schizas et al. (2016) are not the only colleagues to advocate for a domain-specific, rather than a domain-general approach to NOSK, in science education (e.g., Erduran and Dagher 2014; Matthews 2012; Rudolph 2000). Abd-El-Khalick (2012a, 2014) has addressed the burdens and benefits of the two approaches, including that a domain-specific approach to NOSK shares many of the same conceptual issues often raised by critics of a domain-general approach and that the two approaches could be deployed synergistically. There is, in fact, a rather extensive body of literature (e.g., Abd-El-Khalick 2012a, b; Lederman 2007; Lederman 
and Lederman 2014; Smith et al. 1997) addressing the fact that the consensus list of the characteristics of science is by no means perfect and would not be accepted in toto by most philosophers. However, at the same time, it is widely adopted by science educators as appropriate for the sort of K-U science instruction we address in this essay. For sure, there are different conceptions of scientific literacy and NOSK (Kaya et al. 2019), but what is important here is the focus on what student knowledge of science is likely to be useful/valuable to members of the public and what understandings of NOSK are likely to be appropriate to the capabilities of the majority of our students (Kampourakis 2016). In our view, the consensus view of NOS meets both these criteria, and there is a stronger body of empirical evidence for that claim than there is for a NOSs approach.

\section{So, What Should We Teach K-U Students About NOSK?}

For science educators who share our position, the next question is as follows: Which aspects of NOSK should we emphasize for our learners? Given that there are virtually no separate courses on NOSK offered at the K-12 level, and few-if any, NOSK-specific introductory and intermediate university science courses, instructional emphasis on NOSK must be integrated into the science curriculum, whether it be biology, chemistry, physics, or earth, and space science. The following criteria provide some concrete guidelines that should ensure, as much as possible, that NOSK understandings can be effectively and pragmatically taught. The NOSK aspects addressed should be as follows:

1. Explicitly connected to the science concepts and practices included in the particular science curriculum or course;

2. Developmentally/age appropriate for learners' age, grade level, and abilities (see Abd-ElKhalick (2014) for an example of a developmental framework for benchmarking NOS understandings in K-U students);

3. Supported by empirical evidence that students can successfully understand the concepts addressed;

4. Contain few philosophically nuanced and contentious claims; and

5. Be clearly connected to the achievement of scientific literacy and students' ability to make informed decisions about global, societal, and personal issues that are science based.

These criteria provide some guidance in terms of what should and can be taught with respect to NOSK, but this is just one part of the problem. Perhaps a greater problem than quibbling about what aspects should be addressed, is arguing about how to best teach NOSK. While the research on university science course instructors is still emerging, there is overwhelming research evidence demonstrating that most K-12 classroom science teachers do not have adequate understandings of NOSK regardless of the various aspects that are promoted (Lederman 2007; Lederman and Lederman 2014), which would be a logical prerequisite to an NOSK approach. Over the past few decades, it has become clear that an explicit, reflective approach to teaching NOSK to K-12 students and science teachers (who are university learners) is more effective than assuming that learners will develop understandings simply by doing scientific investigations. The latter approach is generally known as an implicit approach (Abd-El-Khalick and Lederman 2000). What has not been made clear, or has been misunderstood by readers of the literature, is what is meant by explicit, reflective teaching of 
NOSK. For example, some (e.g., Duschl and Grandy 2013) have misrepresented the explicit, reflective approach as the science teacher or science course instructor simply pointing out during a lesson or activity where an aspect of NOSK is relevant. Let us be explicit about what it means to be "explicit": it does not mean direct instruction or a lecture. The key is asking the types of questions that cause students to reflect on what they have done and concluded within a scientific investigation. For example, while debriefing a class investigation (where students have worked in groups), it becomes clear that not all groups have arrived at the same conclusions. The usual approach to this result in most science classrooms is that the teacher conveys that someone must have done something wrong. That is, not everyone arrived at the same desired results. A more appropriate approach by the teacher committed to the explicit/ reflective approach, that is, a teacher aiming for student understanding of NOSK would be to ask the class why everyone did not get the same answer. Naturally, some students will claim that students in dissenting groups did something "wrong." But, the expert teacher should delve further; they might ask the class for other possible reasons why laboratory group results disagreed. Is it possible that everyone followed the instructions, but did not get the same result? What are some reasons, other than someone doing something wrong? Is such disagreement also possible among scientists? Why do scientists disagree? Eventually, this line of questioning will lead to discussions about scientists and students being different people-with differing expertise, theoretical commitments, and past experiences - and even after generating the same set of data, they still might interpret these data differently. This is why we say that conclusions and scientific knowledge are theory-laden and involve subjectivity and creativity, and are always tentative. This is much different from the teacher simply and didactically, as surmised by Duschl and Grandy (2013), telling students that the reason different scientist groups arrived at different conclusions was a result of certain aspects of NOS.

Perhaps another example is in order to make our point as explicit as possible. A very popular laboratory activity used by biology instructors while teaching about mitosis is to have students look at onion root tip cells and classify the stage of mitosis each of the cells observed is in. Students collect data from three fields of view under the microscope and use the data to eventually calculate the relative time each stage of mitosis takes. This can be a somewhat unfortunate activity in terms of NOSK and inquiry, but it is nevertheless quite popular. During the debriefing of this activity, the explicit/reflective teacher could ask the following:

1. Why did you use three fields of view instead of five?

2. Did you have difficulty deciding exactly which stage some cells were in, for example, prophase or interphase?

3. How definite is the separation of one phase from another? How might this contribute to the differences in the results of different groups of students?

4. Did the same group member do all of the observation of cells or did you divide the work among team members?

5. Does it make a difference whether different people or the same people did the observation of cells?

These questions can lead to discussions of theory-ladenness and tentativeness, as well as discussions about scientific inquiry. Again, the teacher never tells the students what is involved, but asks questions that stimulate students to discuss some aspects of NOSK, which are eventually named. The naming of the various NOSK characteristics is the last thing 
learned, after the NOSK concepts have been understood. It is not didactic and it is not a lecture. This is what is meant by the explicit, reflective approach to teaching NOSK.

The content examples used here are part of many science curricula and illustrate ways NOSK can be integrated in the curriculum as opposed to requiring a separate course in NOSK. Again, the literature clearly supports an explicit, reflective approach to teaching NOSK. It would be misguided to assume that students will come to understand NOSK simply by doing science investigations. But one can see from these examples that there is a logical pedagogical connection between how students experience scientific inquiry and learning about NOSK.

A brief note on the meaning of the term "reflective" is also necessary. Occasionally, the authors of this manuscript have encountered science instructors or researchers who seem to misinterpret the term as one would refer to a mirror, i.e., as a quick, automatic reflection of what the student has just been taught, such as multiplication table drills. The science teacher with this misconception, for another example, might give a mini-lecture and immediately ask the students to regurgitate what they had just been told in a post-test. In contrast, we take for the term "reflective" to refer to the act of student contemplation, of mentally struggling with the meaning of their learning experiences. Thus, one might identify "reflective" teaching by asking if the instruction is student-centered and requires careful and extended thought. As another example, in a unit on NOS and evolution, Scharmann et al. (2005) asked students to respond to "thought questions" related to the class activity of the day and to submit their responses to the instructor by email, which then often continued as a one-on-one electronic conversation guided by continued open-ending questioning by the teacher.

A final point to note is that although science is the best means we have for a rational understanding of nature, it can also be messy and quite different from the cook-book type laboratory activities often conducted at schools. Science is about knowledge and understanding, but it is also filled with ignorance, failure, and uncertainty (Firenstein 2012, 2015; Kampourakis and McCain 2019).

\section{Assessing Nature of Scientific Knowledge}

All K-U science teachers should recognize that what we are teaching must be assessed; otherwise, student learning is likely compromised. This teaching and learning precept has been called "WYTIWYG" (pronounced "whit-e-wig") or "what you test is what you get." Students need to know that what a teacher values as an outcome of learning is important enough to be assessed, and if a teacher does not address this, learners will ask: "Will this be on the test?" Good or bad, this is reality. Comprehensive reviews and support for various assessments of NOSK can be found in Abd-El-Khalick (2014), Lederman (2007), Lederman et al. (2002). Abd-El-Khalick (2014) and other reviews of assessments directly assess the validity and reliability of the various assessments.

NOSK can be assessed in a variety of ways, convergent questionnaires, student behaviors, open-ended questionnaires, and interviews. All of these approaches are discussed in Abd-ElKhalick (2014) and Lederman (2007) with the conclusion that interviews and open-ended questionnaires are the most accurate measures of what students know. But, the latter approaches are labor intensive. We believe that the most effective and pragmatic approach for classroom teachers is to selectively include some of the open-ended questions included in the Views of Nature of Science (VNOS) buffet of assessments in class assessments (see Lederman et al. 2002). In essence, these would constitute essay questions within regular science class 
assessments or science classroom investigations. If teachers want to validly assess what students are thinking about higher level concepts, such as NOSK, multiple choice or convergent types of assessments are not adequate. Additionally, a main conclusion from empirical research is that simply observing students' behaviors during a science activity is not a valid way to assess their understandings of NOSK. Indeed, it makes little sense to assume that a student who accepts that scientific knowledge is tentative will behave any differently while doing a laboratory investigation than a student who believes that scientific knowledge is absolute. The difference between how students behave and what they actually accept as true is well established with respect to NOSK (Abd-El-Khalick 2012b; Lederman 2007).

\section{Summary}

The focus of this editorial has been on a pragmatic and research-guided approach to teaching NOSK. We have provided guidelines for selecting aspects of NOSK to include within instruction. In general, the aspects of NOSK should be directly connected to the science curriculum, taught in an explicit/reflective manner, and purposely assessed along with the other science concepts taught. This domain-general approach is supported by extensive empirical literature and is substantially more effective than implicit approaches (Abd-ElKhalick and Lederman 2000). Students have little difficulty in describing the gross differences among the various sciences, but most have considerable difficulty describing why the various sciences are all considered to be science and other candidates (e.g., intelligent design) are not. The documented inability of the public to distinguish between scientific and non-scientific claims (e.g., National Science Board 2016) further emphasizes the importance of focusing on the similarities among the sciences as opposed to stressing the more esoteric differences. In essence, a call for such domain-specific NOSs could simply be interpreted as a straw man argument: the domain-general NOS approach by definition seeks to identify characteristics that are common to the sciences, not to distinguish among them. Additionally, the empirical evidence supports the idea that the domain-general approach provides a sound and powerful platform or framework to effectively and eventually introduce students to domain-specific aspects of various sciences (Abd-El-Khalick 2012a). Once such an introduction is successfully made, one can then proceed to more advanced topics. However, it is important to recognize that the nuances about NOSK that are related to specific science disciplines, is most appropriate for advanced students with extensive expertise in the sciences.

\section{Compliance with Ethical Standards}

Conflict of Interest The authors declare that they have no conflict of interest.

\section{References}

Abd-El-Khalick, F. (2012a). Examining the sources for our understandings about science: enduring conflations and critical issues in research on nature of science in science education. International Journal of Science Education, 34(3), 353-374. 
Abd-El-Khalick, F. (2012b). Nature of science in science education: toward a coherent framework for synergistic research and development. In B. J. Fraser, K. Tobin, \& C. McRobbie (Eds.), Second international handbook of science education (Vol. 2) (pp. 1041-1060). The Netherlands: Springer.

Abd-El-Khalick, F. (2014). The evolving landscape related to assessment of nature of science. In N. G. Lederman \& S. K. Abell (Eds.), Handbook of research on science education (2nd ed., pp. 621-650). Mahwah: Lawrence Erlbaum.

Abd-El-Khalick, F., \& Lederman, N. G. (2000). Improving science teachers' conceptions of the nature of science: a critical review of the literature. International Journal of Science Education, 22(7), 665-701.

Duschl, R. A., \& Grandy, R. (2013). Two views about explicitly teaching nature of science. Science \& Education, 22(9), 2109-2139.

Erduran, S., \& Dagher, Z. (2014). Reconceptualizing the nature of science for science education. Dordrecht: Springer.

Feynman, R. P., \& Cashman, D. (2013). The pleasure of finding things out. Blackstone Audio, Incorporated.

Firenstein, S. (2012). Ignorance: how it drives science. New York: Oxford University Press.

Firenstein, S. (2015). Failure: why science is so successful. New York: Oxford University Press.

Kampourakis, K. (2016). The "general aspects" conceptualization as a pragmatic and effective means to introducing students to nature of science. Journal of Research in Science Teaching, 53(5), 667-682.

Kampourakis, K., \& McCain, K. (2019). Uncertainty: how it makes science advance. New York: Oxford University Press.

Kaya, E., Erduran, S., Aksoz, \& Akgun, S. (2019). Reconceptualized family resemblance approach to nature of science in pre-service science teacher education. International Journal of Science Education, 41(1), 21-47.

Lederman, N. G. (2007). Nature of science: past, present, and future. In S. K. Abell \& N. G. Lederman (Eds.), Handbook of research on science education (pp. 831-879). Mahwah: Lawrence Erlbaum.

Lederman, N. G., \& Lederman, J. (2014). Research on teaching and learning of nature of science. In N. G. Lederman \& S. K. Abell (Eds.), Handbook of research on science education (Vol. 2, pp. 600-620). Mahwah: Lawrence Erlbaum.

Lederman, N. G., Abd-El-Khalick, F., Bell, R. L., \& Schwartz, R. S. (2002). Views of nature of science questionnaire: toward valid and meaningful assessment of learners' conceptions of nature of science. Journal of Research in Science Teaching, 39(6), 497-521.

Matthews, M. R. (2012). Changing the focus: from nature of science (NOS) to features of science (FOS). In M. S. Khine (Ed.), Advances in nature of science research: concepts and methodologies (pp. 3-26). Dordrecht: Springer.

National Research Council (NRC). (1996). National science education standards. Washington, DC: National Academies Press.

National Science Board. (2016). Science and engineering indicators 2016. Arlington, VA: National Science Foundation (NSB-2016-1).

NGSS Lead States. (2013). Next generation science standards: for states, by states. Washington, DC: The National Academies Press.

Rudolph, J. L. (2000). Reconsidering the "nature of science" as a curriculum component. Journal of Curriculum Studies, 32(3), 403-419.

Scharmann, L. C., Smith, M. U., James, J. C., \& Jensen, M. (2005). Explicit reflective nature of science instruction: evolution, intelligent design \& umbrellaology. Journal of Science Teacher Education, 16(1), 27-41.

Schwartz, R., \& Lederman, N. (2008). What scientists say: scientists' views of nature of science and relation to science context. International Journal of Science Education, 30(6), 727-771.

Schizas, D., Psillos, D., \& Stamou, S. (2016). Nature of science or nature of the sciences? Science Education, 100(4), 706-733.

Smith, M. U., Lederman, N. G., Bell, R. L., McComas, W. F., \& Clough, M. P. (1997). How great is the disagreement about the nature of science: a response to alters. Journal of Research in Science Teaching, 34(10), 1101-1103.

Publisher's Note Springer Nature remains neutral with regard to jurisdictional claims in published maps and institutional affiliations. 